\title{
Alternative fuels from forest residues for passenger cars - an assessment under German framework conditions
}

\author{
Oliver Hurtig ${ }^{1 *}$, Ludwig Leible', Stefan Kälber', Gunnar Kappler ${ }^{1}$ and Ulrich Spicher ${ }^{2}$
}

\begin{abstract}
Background: Due to the available volumes, biogenic residues are a promising resource for renewable fuels for passenger cars to reduce greenhouse gas (GHG) emissions. In this study, we compare three fuels from forest residues under German framework conditions: biogenic electricity, substitute natural gas (SNG), and Fischer-Tropsch (FT) diesel.
\end{abstract}

Methods: Fuels from forest residues are compared with regard to their technical efficiency (here defined as 'pkm per kg biomass'), costs, and environmental impacts with a focus on GHG emissions. We took into consideration the real-life driving conditions and corresponding car classes as well as market penetration scenarios for electric and gaseous fuel cars.

Results: Our results show that the technical efficiency of biogenic electricity is high, while the economic and environmental results strongly depend on the car size and market penetration assumptions. Furthermore, it is essential to clearly define the main goal of introducing fuels from forest residues. If the goal is to reduce GHG emissions at the lowest cost, SNG (and natural gas) in bigger cars is preferable. For high GHG reductions at the lowest forest residue consumption, biogenic electricity in smaller commuter-type cars are found to be a good solution. This also proves true for the aggregated environmental impact score ReCiPe Total.

Conclusions: It is important to include mobility patterns and a clear goal definition when comparing biogenic fuels. In Germany, biogenic electricity, SNG, and FT diesel can reduce GHG emissions at reduction costs of around $100 € / \mathrm{t} \mathrm{CO}$-Eq when used the right way.

Keywords: Biogenic fuels; Passenger cars; Environmental impacts; Greenhouse gas emissions; Fuel life cycle; Car life cycle

\section{Background}

Conventional fuels for passenger cars originating from crude oil or natural gas, such as gasoline, diesel, and compressed natural gas (CNG) have several drawbacks. First, the greenhouse gas (GHG) emissions resulting from their combustion contribute to global warming; around $1 / 4$ of the GHG emissions in Europe are caused by the transport sector, including passenger cars [1]. Furthermore, crude oil and natural gas are not only finite resources but must also be imported. Facing these

\footnotetext{
* Correspondence: oliver.hurtig@zoho.com

${ }^{1}$ Institute for Technology Assessment and Systems Analysis (ITAS), Karlsruhe 76021, Germany

Full list of author information is available at the end of the article
}

challenges, research is being undertaken to identify alternative fuels and to develop new engine technologies that can replace them as primary energy sources for passenger car fuels. One possibility to produce such alternative fuels is to use biogenic residues as an energy source. Among these, forest residues represent the largest biomass volume available for energy purposes [2].

In addition to the environmental effects, strategies to reduce GHG emissions in the long term must also consider technical and economic aspects. From a consumer's point of view, a new fuel/propulsion system will only be interesting if its driving parameters (acceleration, range, etc.) will be comparable to those of existing alternatives at a reasonable price. From a political point of 
view, it is also important to reach emission reductions at low costs. Without alternative fuels, substantial emission reductions will be hard to achieve for Germany.

We therefore assess the most efficient way to use fuels from forest residues for passenger cars under technical, economic, and environmental aspects for German framework conditions. These framework conditions include German and European legislation like the Renewable Energy Directive (2009/28/EC) as well as driving habits and economic situation. Three fuels are compared: biogenic electricity, substitute natural gas (SNG), and FischerTropsch (FT) diesel. The three renewable fuels can replace their fossil equivalents (electricity, CNG, and diesel) without any modification of the propulsion technology of the car.

All fuels are compared to diesel as reference fuel to determine their technical and economic efficiency in reducing GHG emissions. Diesel is chosen as a reference because it has a high market share in Germany and generally has lower GHG emissions than gasoline [3].

We put an emphasis on driving patterns, car types, and driving cycles to establish realistic use cases for different car users.

\section{Methods}

This paper is based on a detailed model that integrates technical parameters, costs, GHG emissions, and other environmental impacts over the whole well-to-wheel chain and the car life cycle and allows the techno-economic and environmental assessment presented in Figure 1 to be performed. Subsections 'Fuel choice and system boundaries' to 'Cost-effectiveness analysis: GHG mitigation costs' explain the methods and their application in the presented model in more detail.

\section{Fuel choice and system boundaries}

Figure 2 gives an overview of the system studied including the fuel production chains and the use phase. All three fuels are produced from the same forest residue stock via combustion or via a combination of gasification, methanation, FT synthesis, and conditioning steps. The fuels are distributed to filling stations or power outlets and stored in a car adapted for the fuel. The car uses the fuel to drive one passenger kilometer ( $\mathrm{pkm}$, the equivalent of driving one passenger over the distance of one kilometer). Production, maintenance, and end of life of each technology-especially of the cars, but also of the fuel production plants - are included in the systems analysis as well (this is not explicitly shown in Figure 2).

Each car - electric, gaseous fuel, and diesel - can also be powered by a fossil reference fuel: electricity from the German production mix (called 'electricity mix' from here on), natural gas, or diesel. Diesel is used as a reference for the biogenic fuels. Electricity mix and natural gas are often discussed as alternative fuels and are therefore included in the study to show their performances. Nevertheless, they are not the focus of the study.

\section{Driving cycles and mobility patterns}

Most comparisons of alternative fuels and propulsion systems are based on generic cars in combination with common driving cycles (like the New European Driving Cycle) although it has been shown that the choice of cars and driving cycles has an important influence on costs and emissions [4] and, therefore, on the outcome of the assessment. Differences between driving cycles can easily amount to $20 \%$ of fuel consumption and tailpipe emissions [5] and can differ largely for different fuels. This is why the ARTEMIS driving cycle has been used in the model.

Two different mobility patterns have been extracted from the literature and used for the model. The requirements for each pattern were used to define a characteristic car and a driving pattern consisting of a speed profile, the yearly driven distance, and occupancy rate.

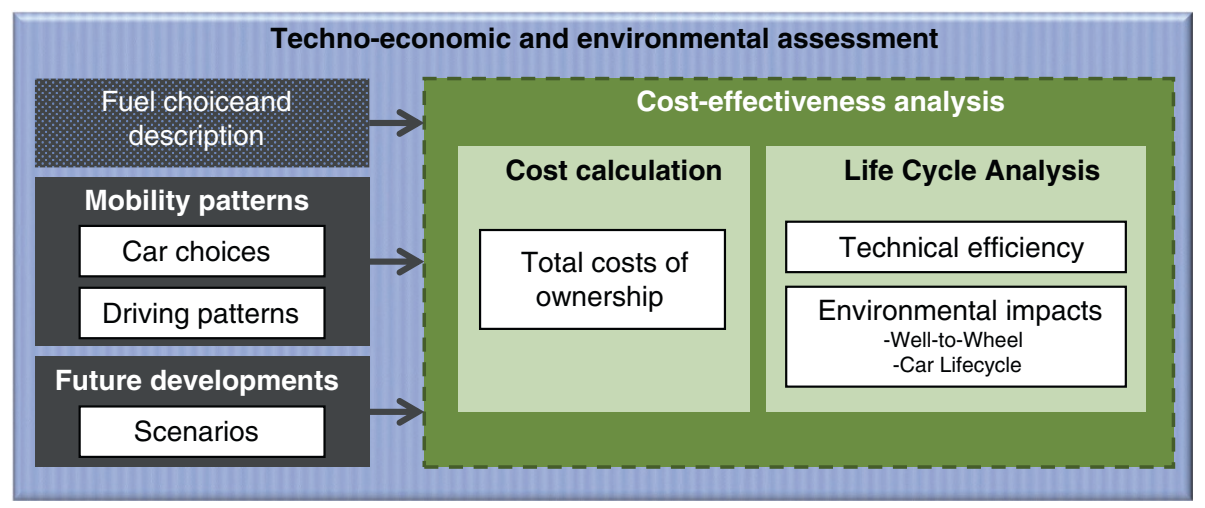

Figure 1 Schematic of the underlying methods. 


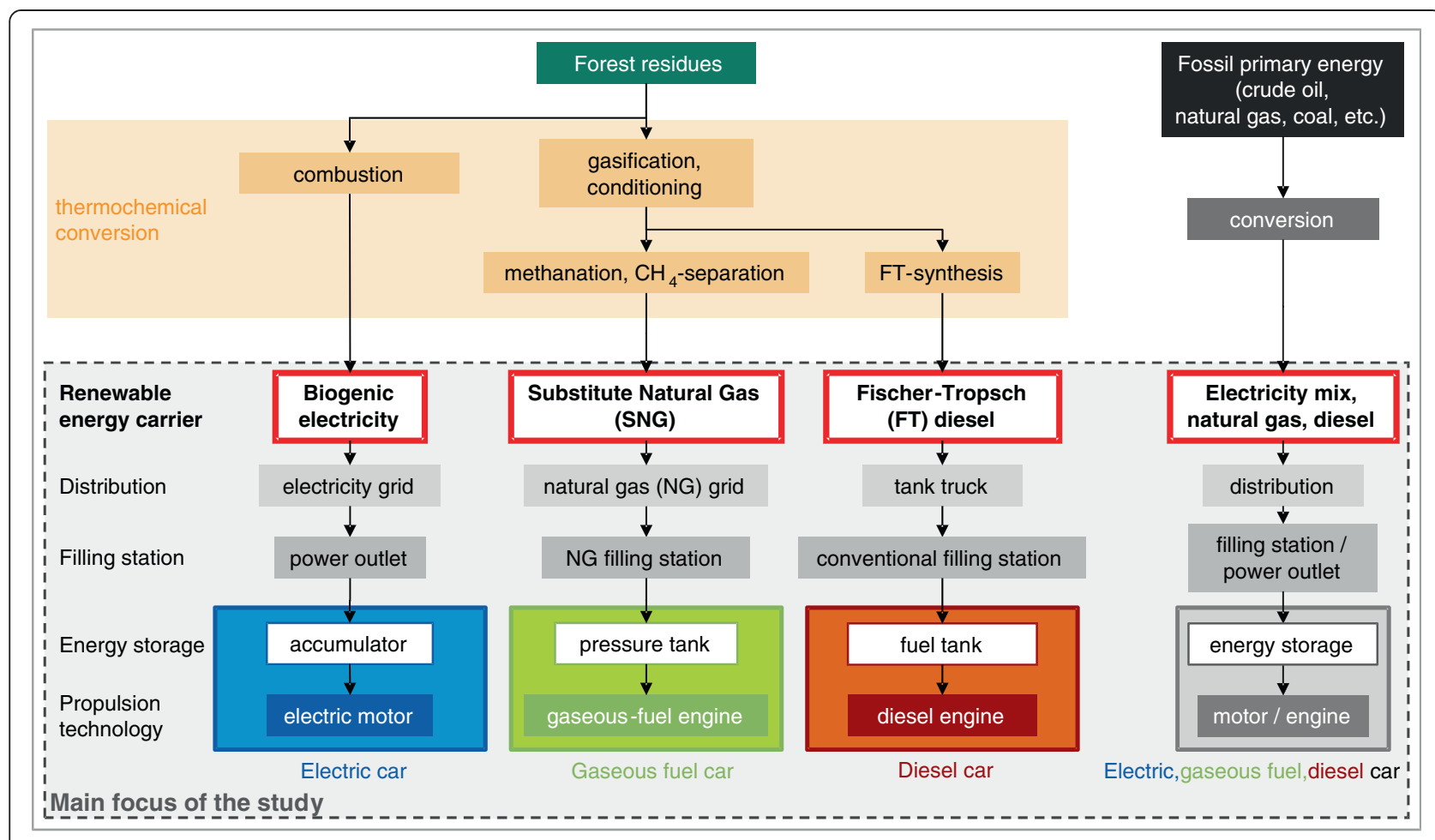

Figure 2 Fuel chains of biogenic electricity, SNG, and FT diesel from forest residues and their fossil reference fuels.

\section{Future developments}

For prospective analyses, it is important to consider future developments and to compare the alternatives for future points in time. This way, technologies that are not yet available on the market can be compared more equitably with already established technologies by taking into account learning curves and technological progress. Furthermore, scientific policy advice aims at supporting policy decisions affecting the future. Therefore, one car life cycle for a car purchased in the year 2020 is analyzed.

For the cars, emerging markets are analyzed. For each fuel, the acquisition (and therefore construction) of a new car adapted for that fuel is considered in the model. A scenario for equilibrium markets (only replacement of the fuel, without car life cycle) can be found in [6].

The scenario methodology (for details, see, e.g., [7]) helps to cope with uncertainties arising from the comparison in the future by modeling different possible developments.
We defined three scenarios: business as usual (B), gas age (G), and e-mobility age (E). Based on the assumed number of worldwide ${ }^{\mathrm{a}}$ produced cars with the three propulsion technologies shown in Table 1, the car parameters (vehicle costs, fuel consumption, etc.) are adapted via literature research and learning curves to build a coherent scenario. Additional information is given in Tables 2 and 3, and in the subsection 'Economic analysis' in Additional file 1.

\section{Cost calculation}

Costs as a decisive factor for investment decisions can best be compared as total costs of ownership (TCO) for the consumer (for a detailed discussion, see [54]).

Most of the analyzed technologies are not implemented on large scale at the time of this analysis. Therefore, significant economies of scale can be expected up to the year 2020, meaning that the costs of new cars tend to get lower when they are produced in larger

Table 1 Assumed worldwide production of electric, gaseous fuel, and diesel cars in the year 2020

\begin{tabular}{|c|c|c|c|c|}
\hline Worldwide car production, in million cars/year & Business as usual (B) & Gas age (G) & E-mobility age (E) & As comparison: $2011^{a}$ \\
\hline Electric cars & 1.0 & 1.0 & 4.1 & $<0.1$ \\
\hline Gaseous fuel cars & 1.8 & 6.0 & 1.8 & Approximately 2.6 \\
\hline Diesel cars & 29.0 & 29.0 & 29.0 & Approximately 19.0 \\
\hline Total cars & 78.0 & 78.0 & 78.0 & Approximately 59.9 \\
\hline
\end{tabular}


Table 2 Technical, economic, and environmental parameters and impacts of fuel production

\begin{tabular}{|c|c|c|c|c|c|c|c|}
\hline & Biogenic elec. & Elec. mix (fossil) & & & CNG (fossil) & FT diesel & Diesel (fossil) \\
\hline 2020 scenario $^{a}$ & & & G & $\mathrm{B}, \mathrm{E}$ & & $\overline{E, G}$ & \\
\hline
\end{tabular}

Technical, biomass per $\mathrm{kWh}$ fuel $\left[\mathrm{kg}_{50 \%} \text { dry matter } / \mathrm{kWh}_{\text {fuel, at tank }}\right]^{\mathrm{b}}$

$$
2.13
$$

Economic, fuel costs at filling station (excl. taxes) $\left[\epsilon_{2011}-\mathrm{ct} / \mathrm{kWh}_{\text {fuel }}\right]^{\mathrm{c}}$

$\begin{array}{lllllllll}2020^{\mathrm{d}} & 18.5 & 16.2 & 13.4 & 14.1 & 5.7 & 16.0 & 20.0 & 7.6 \\ 2031^{\mathrm{d}} & 17.1 & 16.5 & 11.3 & 12.1 & 6.0 & 13.0 & 14.5 & 8.2\end{array}$

Environmental, GHG emissions (well to tank) $\left[\mathrm{g} \mathrm{CO}_{2}-\mathrm{Eq} / \mathrm{kWh} \mathrm{fuel}^{\mathrm{e}}\right.$

$$
17 \text { to } 18^{f} \quad 766^{f}
$$

58

53

45

${ }^{\mathrm{a}} \mathrm{B}$, business as usual; $\mathrm{G}$, gas age; $\mathrm{E}$, e-mobility age. Biogenic electricity costs were not varied because biogenic electricity use is not dominated by cars. ${ }^{\mathrm{b}}$ The used forest residue wood has a lower heating value of approximately $2.2 \mathrm{kWh} / \mathrm{kg}$ and a moisture content of $50 \%$. All efficiencies are net efficiencies; production plant consumptions were subtracted. No byproducts were considered or used in the process.

'Derived from: biogenic electricity, production costs $11 \mathrm{ct} / \mathrm{kWh}$ [11]; electricity mix, production costs 4.1 to $7.5 \mathrm{ct} / \mathrm{kWh}$; transport, marketing, and margin 6 to 13 $\mathrm{ct} / \mathrm{kWh}$ [12-15]; SNG, production costs 5.6 to $13.3 \mathrm{ct} / \mathrm{kWh}$ [16]; CNG, production costs 1.0 to $6.4 \mathrm{ct} / \mathrm{kWh}$; transport, compression, marketing, and margin 1.6 to $3 \mathrm{ct} / \mathrm{kWh}$ [12,17-19]; FT diesel, production costs 6.9 to $11.2 \mathrm{ct} / \mathrm{kWh}$ [11,20,21]; diesel, production costs 2.2 to $9.6 \mathrm{ct} / \mathrm{kWh}$; transport, marketing, and margin 1.5 to $2.6 \mathrm{ct} / \mathrm{kWh}$ [19,22-24]; ${ }^{d}$ linear slope of costs between 2020 and 2031; ${ }^{\circ}$ Calculated using ecoinvent 2.2 database [25] with the following modifications, electricity mix based on [26,27]; SNG and FT diesel based on $[11,16]$; ${ }^{f}$ Depending on the number of installed public charging stations. Lower value for scenario $E$.

numbers. We used the most common mathematical representation of learning curves from [55] to estimate future costs of new technologies such as traction batteries and CNG propulsion systems (c.f. subsection 'Economic analysis' in Additional file 1).

All costs were summed up via the net present value method [56] to account for the temporal occurrence of different costs. We chose a discount factor of $6 \%$ throughout the study (c.f. Additional file 1 for discussion). All costs were additionally inflation-adjusted for the year 2011 to make them comparable. The cost of an alternative was then calculated according to the following Equations 1 and 2:

$$
\begin{aligned}
\mathrm{TCO}_{\boldsymbol{i}, \boldsymbol{a}} & =\sum_{\boldsymbol{t}=\boldsymbol{t}_{0}}^{T} \boldsymbol{c}_{\boldsymbol{t}} \times(1+\boldsymbol{d})^{-\left(\boldsymbol{t}-\boldsymbol{t}_{0}\right)} \\
\mathrm{TCO}_{\boldsymbol{e}, \boldsymbol{a}} & =\mathrm{TCO}_{\boldsymbol{i}, \boldsymbol{a}}-\sum_{\boldsymbol{t}=\boldsymbol{t}_{0}}^{T} \boldsymbol{s}_{\boldsymbol{t}} \times(1+\boldsymbol{d})^{-\left(\boldsymbol{t}-\boldsymbol{t}_{0}\right)}
\end{aligned}
$$

\begin{tabular}{|c|c|c|c|c|c|c|c|c|c|c|c|c|}
\hline \multirow{3}{*}{$\begin{array}{l}\text { Motor } \\
2020 \text { scenario }^{a}\end{array}$} & \multicolumn{6}{|c|}{ Commuter car } & \multicolumn{6}{|c|}{ All-purpose car } \\
\hline & \multicolumn{2}{|c|}{ Electric } & \multicolumn{2}{|c|}{ Gaseous fuel } & \multicolumn{2}{|c|}{ Diesel } & \multicolumn{2}{|c|}{ Electric } & \multicolumn{2}{|c|}{ Gaseous fuel } & \multicolumn{2}{|c|}{ Diesel } \\
\hline & $\mathrm{E}^{\mathbf{b}}$ & $B, G^{c}$ & $\mathbf{G}$ & $\mathrm{B}, \mathrm{E}$ & B & $\overline{E, G}$ & $\mathrm{E}^{\mathrm{b}}$ & $\mathrm{B}, \mathrm{G}^{\mathrm{C}}$ & G & $\mathrm{B}, \mathrm{E}$ & B & $E, G$ \\
\hline \multicolumn{13}{|l|}{ Technical parameters } \\
\hline Mass of glider $[\mathrm{kg}]^{\mathrm{d}}$ & \multicolumn{6}{|c|}{595} & \multicolumn{6}{|c|}{1,060} \\
\hline Mass of tank or battery [kg] & 143 & 174 & \multicolumn{2}{|c|}{47} & \multicolumn{2}{|c|}{42} & 710 & 868 & \multicolumn{2}{|c|}{84} & \multicolumn{2}{|c|}{70} \\
\hline Total mass $[\mathrm{kg}]$ & 823 & 854 & 748 & 749 & 757 & 758 & 1,870 & 2,028 & 1,269 & 1,270 & 1,300 & 1,301 \\
\hline Consumption $[\mathrm{kWh} / 100 \mathrm{~km}]^{\mathrm{e}}$ & 13 & 14 & 50.4 & 56.7 & 38.7 & 39.8 & 17.9 & 19 & 57.6 & 64.8 & 59.4 & 61.1 \\
\hline \multicolumn{13}{|c|}{ Economic, costs (excl. taxes) $\left[\epsilon_{2011}\right]$} \\
\hline Glider $^{f}$ & \multicolumn{4}{|c|}{9,000} & & & \multicolumn{6}{|c|}{18,700} \\
\hline Energy storage $^{b, c}$ & 6,231 & 8,354 & 576 & 633 & 100 & & 30,824 & 41,578 & 720 & 792 & 100 & \\
\hline Total car acquisition & 16,231 & 18,354 & 13,388 & 13,606 & 12,000 & & 50,254 & 61,278 & 23,051 & 23,167 & 22,700 & \\
\hline \multicolumn{13}{|c|}{ Environmental, car life cycle GHG emissions $\left[t \mathrm{CO}_{2} \text {-Eq/car life }\right]^{\mathrm{g}}$} \\
\hline & 6.4 & 7.0 & 3.4 & & 3.4 & & 20.4 & 23.7 & 5.7 & & 5.8 & \\
\hline
\end{tabular}

where $\mathrm{TCO}_{i, a}$ is the total costs of ownership, including taxes, of alternative $a\left[\epsilon_{2011} / \mathrm{car}\right]$; $\mathrm{TCO}_{e, a}$ is the total costs

Table 3 The technical and economic parameters of the vehicles

Technical, economic, and environmental parameters and impacts of the production of commuter and all-purpose cars with electric, gaseous fuel, and diesel propulsion technology for the three scenarios business as usual (B), gas age (G), and E-mobility age (E) 2020. 'B, business as usual; G, gas age; E, e-mobility age; ${ }^{b} \mathrm{Li}$ ion battery, energy density $145 \mathrm{Wh} / \mathrm{kg}$ based on [28-31]; costs $300 € / \mathrm{kWh}$ based on own learning curves and [15,32-35], c.f. Additional file $1 \mathrm{for}$ details; ${ }^{\mathrm{C}} \mathrm{Li}$ ion battery, energy density $125 \mathrm{Wh} / \mathrm{kg}$, costs $383 € / \mathrm{kWh}$, based on the same sources and learning curves; ${ }^{\mathrm{d}}$ Car without propulsion technology and tank/battery. Optimistic assumptions based on [28,36-41]. ${ }^{~ E l e c t r i c ~ c a r, ~ o w n ~ c a l c u l a t i o n s ~ b a s e d ~ o n ~[42-46] . ~ O t h e r ~ c a r s, ~ b a s e d ~ o n ~[47-52], ~ a n d ~ a p p l i c a t i o n ~ t o ~ w e i g h t e d ~ C A D C ~}$ cycles as described in Table 5. ${ }^{\mathrm{f}}$ Car without propulsion technology, based on car prices in 2011 and [53]; ${ }^{9}$ Calculated using Ecoinvent 2.2 database with several adaptions, including traction battery change. Car operation and fuel production emissions are not included. 
of ownership, excluding taxes, of alternative $a\left[\epsilon_{2011} / \mathrm{car}\right]$; $t$ is the year of expense; $t_{0}$ is the year of car acquisition (2020); $T$ is the year of car scrappage (2032), a mean life time for German cars of 12 years has been assumed [57]; $c_{t}$ is the sum of costs (expenses) or gains in year $t\left[\epsilon_{2011}\right]$; $d$ is the discount rate (6\%); and $s_{t}$ is the taxes and subsidies in year $t\left[€_{2011}\right]$.

Credits like end-of-life traction battery value were considered as negative expenses in Equation 1; car acquisition costs were treated as expenses in the year $t_{0}$.

TCO were then divided by the total passenger kilometers (pkm) covered by car to obtain costs per pkm.

To visualize the importance of the different cost components, the resulting costs in the 'Conclusions' section were grouped in car acquisition costs (or depreciation), fix costs (maintenance and insurance, including traction battery change costs for electric vehicles), and fuel costs, c.f. Table 4.

\section{Life cycle analysis: environmental impacts}

To assess possible emission reductions, the whole system of fuel production and supply, car production, use, maintenance, and disposal was analyzed. This is often called 'well-to-wheel' analysis for the fuel cycle and 'car life cycle' for the production, maintenance, and disposal of the car. The method chosen to model material flows and environmental impacts was a life cycle analysis (LCA), see, e.g., [58-63]. This study respects most of the ISO 14040-44 standards for LCAs, but as the model is also a development of LCA, we do not want to limit it by those standards.

Besides GHG emissions, we analyzed the majority of available environmental impact categories and included the most relevant categories caused by passenger cars as well as the ReCiPe Total score [59] result. Nevertheless, we give priority to GHG emissions as they are the main reason for the development of alternative fuels.

When modeling environmental impacts, we included legislative framework conditions as well as emission limitations: The results should nevertheless not be considered applicable to directives like the Renewable Energy Directive (2009/28/EC) as we adopt a much broader view, including car and fuel production and indirect emissions.

Table 4 Occurrence and grouping of costs

\begin{tabular}{lcc}
\hline Considered expenses $\left(\boldsymbol{c}_{\boldsymbol{t}}\right)$ & Year of occurrence $\boldsymbol{t} \boldsymbol{t})$ & Cost category \\
\hline Car acquisition & 2020 & Car acquisition \\
Maintenance & 2020 to 2031 & Fix costs \\
Insurance & 2020 to 2031 & Fix costs \\
Traction battery change & 2030 & Fix costs \\
Fuel & 2020 to 2031 & Fuel \\
\hline
\end{tabular}

Costs are possibly afflicted with the highest uncertainty for the future and are therefore varied accordingly in the scenarios.

\section{Cost-effectiveness analysis: GHG mitigation costs}

The economic efficiency in reducing environmental impacts is often called cost-effectiveness analysis (e.g., [64]), describing for what costs $\left(€ / \Delta t_{\text {emissions }}\right)$ emission reductions can be achieved.

Mitigation costs are widely used for comparing the cost-effectiveness of different GHG reduction options $[65,66]$. They are calculated as the cost difference for an alternative compared to a reference case divided by the possible emission reduction of this alternative in relation to the reference case:

$$
c_{m, a}=\frac{\mathrm{TCO}_{\boldsymbol{e}, \boldsymbol{a}}-\mathrm{TCO}_{\boldsymbol{e}, \boldsymbol{r}}}{e_{r}-e_{a}} \text { if } e_{r}-e_{a}>0
$$

where $c_{m, a}$ is the mitigation costs of alternative $a$; $\mathrm{TCO}_{e, a}$ is the total costs of ownership, excluding taxes, of alternative $a[€ / \mathrm{pkm}] ; \mathrm{TCO}_{e, r}$ is the total costs of ownership, excluding taxes, of reference (diesel car) $[€ / \mathrm{pkm}] ; e_{r}$ is the emissions of reference (diesel car) $\left[\mathrm{t} \mathrm{CO}_{2}-\mathrm{Eq} / \mathrm{pkm}\right]$; and $e_{a}$ is the emissions of alternative a $\left[\mathrm{t} \mathrm{CO}_{2}-\mathrm{Eq} / \mathrm{pkm}\right]$.

We used a cost difference over emission mitigation plot since it is a simple method to analyze mitigation costs. Constant mitigation costs are presented as straight lines through the origin as done for $100 € / t \mathrm{CO}_{2}$-Eq, which is a typical value for GHG mitigation costs for passenger cars in Germany [67]. Following this approach, the best alternative is placed at the bottom to the right of the chart.

The alternatives can also be compared by giving a monetary value to GHG emission reduction. The best alternative can then be found by applying the following equation to all alternatives and by sorting them by descending values:

$$
K_{a}=e_{r}-e_{a}-\frac{\mathrm{TCO}_{\boldsymbol{e}, \boldsymbol{a}}-\mathrm{TCO}_{\boldsymbol{e}, \boldsymbol{r}}}{m} \text { if } e_{r}-e_{a}>0
$$

where $K_{a}$ is the performance variable of alternative $a ; m$ is the valuation of GHG reduction $\left[€ / t \mathrm{CO}_{2}-\mathrm{Eq}\right]$; $\mathrm{TCO}_{e, a}$ is the total costs of ownership, excluding taxes, of alternative $a[€ / \mathrm{pkm}]$; $\mathrm{TCO}_{e, r}$ is the total costs of ownership, excluding taxes, of reference $r$ (diesel car) [€/pkm]; $e_{r}$ is the emissions of reference (diesel) $\left[t \mathrm{CO}_{2}-\mathrm{Eq} / \mathrm{pkm}\right]$; and $e_{a}$ is the emissions of alternative a $\left[t \mathrm{CO}_{2}-\mathrm{Eq} / \mathrm{pkm}\right]$.

We exemplarily apply Equation 4 with $m=100 € / t$ $\mathrm{CO}_{2}$-Eq for GHG emissions as well as with $m=1 € /$ points for the ReCiPe Total score results.

\section{Data basis and assumptions Fuel production from forest residues}

The three assessed alternative fuels-biogenic electricity, $S N G$, and FT diesel-are produced from forest residues. The forest residues are supplied via tractor, lorry, and train at costs at gate of approximately $90 € / \mathrm{t}$ dry matter [2]. 
Electricity from biomass is produced in a $80-\mathrm{MW}_{\text {th,in }}$ biomass power plant. SNG is produced via gasification, $\mathrm{CO}$ shift, and methanation in a $500-\mathrm{MW}_{\text {th,in }}$ plant. FT diesel uses the same gasification technology, followed by FT synthesis. The refinement takes place in a standard refinery (approximately 1,600 $\mathrm{MW}_{\mathrm{th}, \text { in }}$ ). A diesel yield of about $80 \%$ of the FT raw products was assumed [68]; the other fractions were calculated to be used in their respective sectors with similar GHG reductions as the diesel fraction.

The biogenic fuels were compared to diesel as a reference fuel. Additionally, the two alternative fossil fuels, German electricity production mix (adapted to 2020) and natural gas, were included. No major changes to 2011 were assumed for natural gas and diesel apart from an increased share of biofuels. For more detailed information on fuel production and considerations about marginal and total electricity mix, refer to [6]. The technical, economic, and environmental parameters for all fuels from well to tank are shown in Table 2.

\section{German mobility patterns for passenger cars}

To obtain representative parameters for techno-economic modeling of passenger car fuel use, we analyzed the passenger car statistics and driving patterns in Germany.

Car choices were extracted from historic car sales [69]. The classes mini, subcompact, and half of the compact cars as 'smaller cars' make up for roughly $40 \%$ of German car purchases, as well as the other half of the compact class, middle-sized and upper middle-sized classes and minivans as 'bigger cars' '.

For the driving patterns, a comprehensive study conducted by infas and DLR [70] showed that in Germany, the mean trip length is $15 \mathrm{~km}, 99 \%$ of all trips are shorter than $140 \mathrm{~km}$ (Additional file 1: Figure S3), and the mean daily driving distance is $50 \mathrm{~km}$ (3.4 trips per day on average). These findings indicate that cars with short ranges of about $140 \mathrm{~km}$ could satisfy the vast majority of German car users' needs. On the other hand, the same study states that the $1 \%$ of all trips longer than $140 \mathrm{~km}$ account for $20 \%$ of all kilometers driven by smaller cars and for $32 \%$ of all kilometers driven by bigger cars (Additional file 1: Figure S3). Five percent of all mobile Germans drive more than $200 \mathrm{~km}$ on an average day. These numbers clearly indicate the need for short-range vehicles, just as much as for vehicles capable of longer driving ranges. We correlated these driving patterns with the categorization of 'smaller' and 'bigger' cars.

The car size is also strongly related to the annually covered distances to a category average of $11,500 \mathrm{~km}$ (smaller cars) and of 15,100 km (bigger cars). Ninety percent of the smaller cars cover between 2,000 to 25,000 km per year while $90 \%$ of the bigger cars cover between 3,000 and $35,000 \mathrm{~km}$.
When looking at the reasons for car use, several usage patterns can be identified. One pattern can be defined as 'all-purpose car usage', meaning that one car is used for different purposes such as commuting, shopping, holiday trips, and others. Another important pattern is 'urban commuting', where the car is nearly exclusively used for commuting and for urban trips (as in the case of second cars in some households). We translated these two patterns to the two car categories smaller 'commuter cars' and bigger 'all-purpose cars'.

To compare costs and environmental impacts on a passenger kilometer $(\mathrm{pkm})$ basis, data on the number of passengers per car (occupancy) is required. There is a positive correlation of occupancy and trip length (Additional file 1: Figure S3). While commuter trips and work-related car uses have the lowest, leisure trips have the highest occupancy rate of 1.90 passengers per car. The overall mean occupancy rate is 1.48 for commuter cars and 1.70 for allpurpose cars.

To simulate the driving and measure emissions, driving cycles with a defined speed profile are used. In Europe, it is mandatory for car manufacturers to display the fuel consumption of passenger cars according to the New European Driving Cycle (NEDC). This cycle consists of two parts: an urban part with speeds up to $50 \mathrm{~km} / \mathrm{h}$ and a highway part with speeds up to $120 \mathrm{~km} / \mathrm{h}$. Most of the European models and well-to-wheel analyses use this driving cycle because of the readily available information and the ease of simulation. Unfortunately, the real world consumption and emissions do not correspond well with the NEDC results [4]. Therefore, several more realistic driving cycles have been developed. One of the most representative cycles for European real world driving is probably the Common ARTEMIS Driving Cycle (CADC) [71]. It consists of an urban part (speed up to $50 \mathrm{~km} / \mathrm{h}$ ), a road part (up to $110 \mathrm{~km} / \mathrm{h}$ ), and a motorway part (up to $150 \mathrm{~km} / \mathrm{h}$ ). The accelerations are more realistic and higher speeds are included. As there are three distinct parts, it is possible to weigh these parts depending on the car type and driving patterns.

Based on the information in this section, we chose two driving patterns, 'commuter car' and 'all-purpose car', to represent the use patterns in Germany. Table 5 gives an overview of the most relevant parameters for these patterns.

\section{Car life cycle}

The technical and economic parameters of the vehicles (as defined in Subsection 'Total costs of ownership') are shown in Table 3. All parameters are based on an extensive literature research and on own models (consumption model for the electric car, learning curves for battery and CNG tank costs, environmental model based on Excel, Umberto and Ecoinvent 2.2) and are shown for the three 
Table 5 Driving patterns for the commuter car and for the all-purpose car

\begin{tabular}{lccc}
\hline Size & Unit & $\begin{array}{c}\text { Commuter car } \\
\text { Mini-compact } \\
\text { class }\end{array}$ & $\begin{array}{c}\text { All-purpose car } \\
\text { Compact } \\
\text { class-minivan }\end{array}$ \\
\hline Minimum seats & Seats & 4 & 5 \\
Range & $\mathrm{km}$ & 140 & 400 \\
$\begin{array}{l}\text { Percentage, urban-road- } \\
\text { motorway (CADC) }\end{array}$ & $\%$ & $50-35-15$ & $20-50-30$ \\
$\begin{array}{l}\text { Minimum top speed } \\
\text { Yearly driven distance }\end{array}$ & $\mathrm{km} / \mathrm{h}$ & 130 & 160 \\
Service life & Years & 12,000 & 18,000 \\
\hline
\end{tabular}

scenarios business as usual (B), gas age (G), and E-mobility age $(E)$.

For the use phase, $\mathrm{CO}_{2}$ emissions of fossil fuels were calculated with the following emission factors, $3.15 \mathrm{~kg}_{\mathrm{CO} 2} /$ $\mathrm{kg}_{\text {Diesel }}$ and $2.63 \mathrm{~kg}_{\mathrm{CO} 2} / \mathrm{kg}_{\mathrm{CNG}}$ [25]. $\mathrm{CO}_{2}$ emissions from biogenic fuels are biogenic and were therefore not counted as GHG emissions. All other exhaust emissions, including other GHG emissions $\left(\mathrm{CH}_{4}, \mathrm{~N}_{2} \mathrm{O}\right.$, etc.), were derived from emission measurements [5,72,73]. Emissions from tire and brake wear were adapted from [25]. As their contribution to GHG emissions is small, they were not detailed here.

Maintenance for standard parts (tires, oil, and starter battery) was accounted for, and replacement of the traction battery for the electric car was taken into account for the year 2030 as the lifetime of the battery is assumed to be shorter (10 years) than the lifetime of the car (12 years).
End of life phase was included with respect to the residual value (economic and environmental credit) of the replacement traction battery; the residual value of the car was assumed to be $0 €$. Recycling and landfilling was modeled according to Ecoinvent 2.2.

\section{Results and discussion}

The goal of this study was to assess the technical and economic efficiency of biogenic electricity, SNG, and FT diesel in reducing GHG emissions and other environmental impacts. The presented results all assume that each fuel-car combination replaces a diesel car.

\section{Technical efficiency}

The technical efficiency (passenger kilometers ( $\mathrm{pkm}$ ) per $\mathrm{kg}$ biomass) can be calculated via the fuel production efficiency (Table 2), the fuel consumption of the cars (Table 3), and the mean occupancy of 1.48 and 1.70 for the commuter and all-purpose cars.

Biogenic electricity has a technical efficiency of around $5 \mathrm{pkm} / \mathrm{kg}$ biomass (50\% dry matter) against 1.4 to 1.7 $\mathrm{pkm} / \mathrm{kg}$ for SNG and 0.9 to $1.3 \mathrm{pkm} / \mathrm{kg}$ for FT diesel.

\section{Total costs of ownership}

The costs are shown as total costs of ownership without taxes and subsidies $\left(\mathrm{TCO}_{\mathrm{e}, \mathrm{a}}\right.$, c.f. Subsection 'Cost calculation'). Figure 3 depicts the costs for the commuter and all-purpose cars in the three scenarios B, G, and E.

In general, costs for $1 \mathrm{pkm}$ oscillate around $10 \mathrm{ct} / \mathrm{pkm}$. While costs for the electric commuter car might get nearly competitive in 2020, electric all-purpose cars will still be considerably more expensive than their alternatives

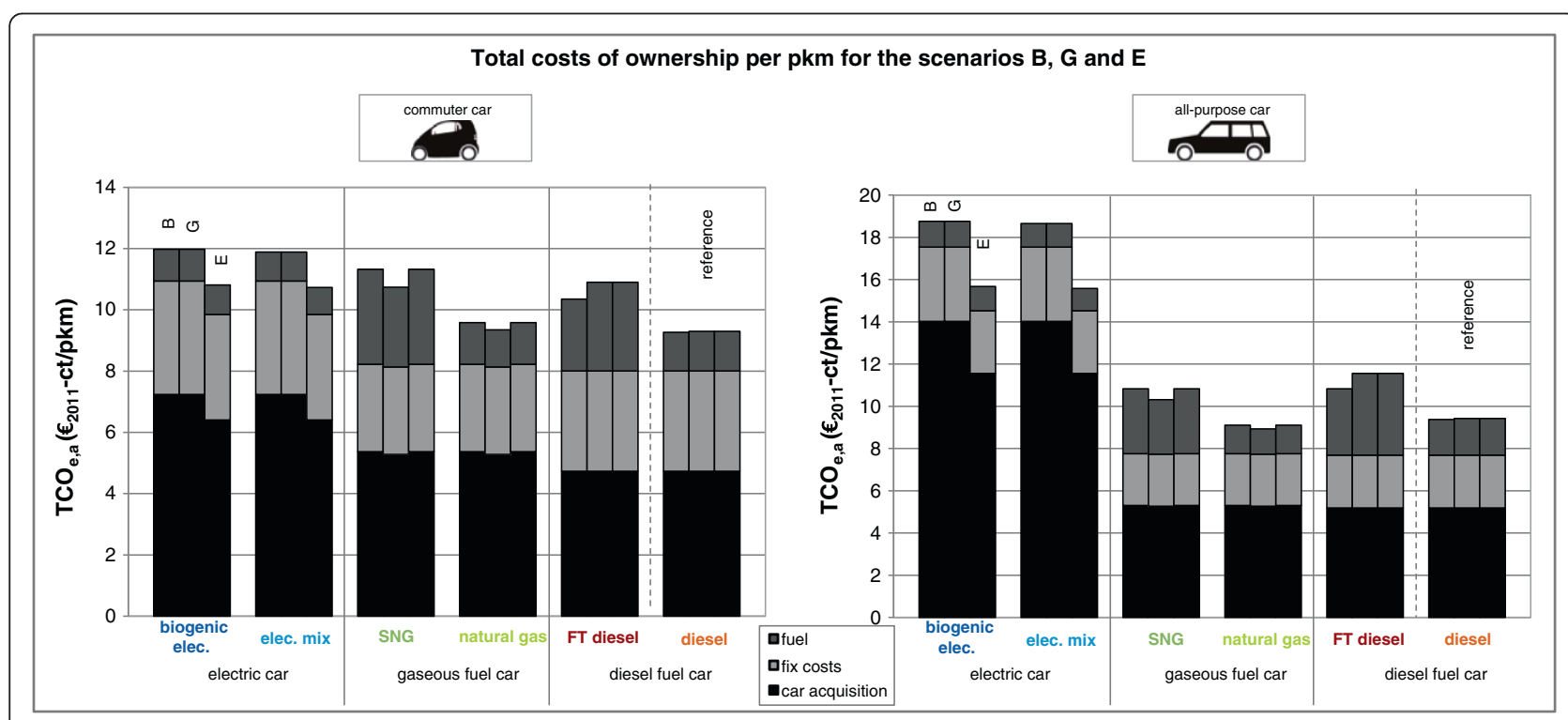

Figure 3 Cost difference over GHG mitigation for all fuels compared to the diesel car. For the year 2020 in Germany. 
(15 to $19 \mathrm{ct} / \mathrm{pkm}$ ) due to the high battery costs. SNG and FT diesel costs will still be higher than those of the fossil diesel reference, by roughly $2 \mathrm{ct} / \mathrm{pkm}$. Because of the importance and uncertainty of TCO, sensitivity analyses have been conducted. They showed that for the commuter car, already a small variation in cost assumptions may change whether SNG or FT diesel was cheaper. Other results do not depend strongly on the input parameters. The most important results of parameter variation are shown in the scenario analyses. Therefore, sensitivity analyses are not presented here.

\section{GHG emissions and other environmental impacts}

As described in Subsection 'Cost-effectiveness analysis: GHG mitigation costs', the environmental impacts were limited to the most relevant categories, with a particular focus on GHG emissions. The fuel and car life cycle were included in the calculations. All results in Figure 4 are displayed with mean value and range for all three scenarios as an improvement in comparison to a diesel car.

FT diesel is found to save the most GHG, followed by biogenic electricity for the commuter car and SNG for the all-purpose car. The differences between the commuter and the all-purpose car arise mainly from the different weighting of the urban, road, and motorway parts of the driving cycle (c.f. Table 5), as well as from the needed battery size for the electric vehicle.

The parts of car production, fuel production, and distribution as well as the driving (exhaust emissions) of the GHG emissions are displayed in Table 6 for the commuter car. This also explains why in this specific case, natural gas has higher GHG emissions than diesel: the gas compression at the fuel station consumes electricity with a high GHG footprint.

For some other important environmental impacts like terrestrial eutrophication ${ }^{c}$, FT diesel is the worst

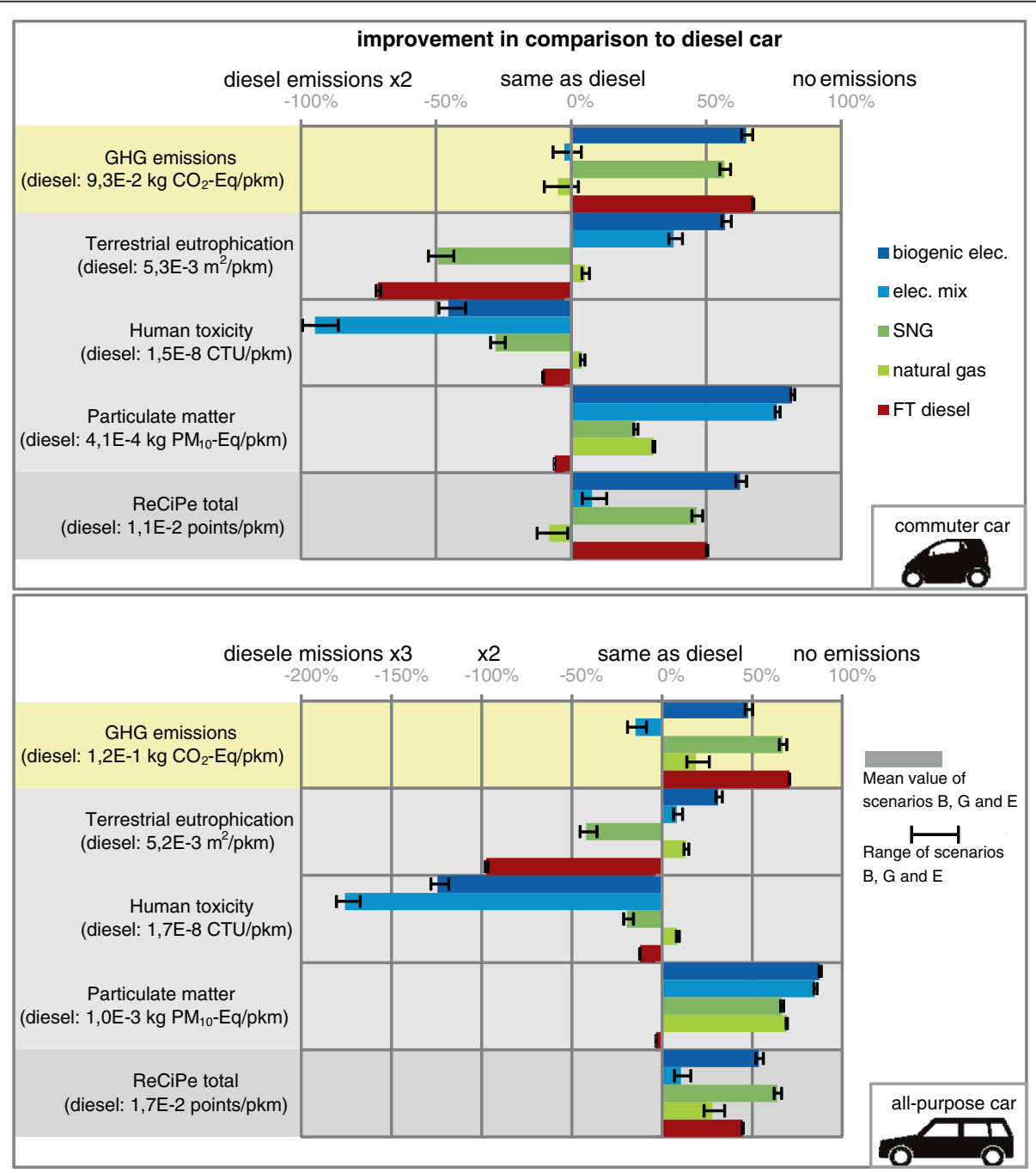

Figure 4 Total costs of ownership without taxes for the scenarios B, G, and E. In the year 2020 in Germany. 
Table 6 GHG emissions for the commuter car during car production, fuel production, and during driving phases

\begin{tabular}{|c|c|c|c|c|c|c|}
\hline GHG emissions, in $\mathrm{g} \mathrm{CO}_{2}-\mathrm{Eq} / \mathrm{pkm}$ & Biogenic elec. & Elec. mix & SNG & Natural gas & FT diesel & Diesel \\
\hline Car production & 32.8 & 32.8 & 15.9 & 15.9 & 15.7 & 15.7 \\
\hline Fuel production and distribution & 1.6 & 66.7 & 25.6 & 21.4 & 13.9 & 11.7 \\
\hline Driving & 0.0 & 0.0 & 0.4 & 65.1 & 1.0 & 65.8 \\
\hline
\end{tabular}

alternative, followed by SNG. These impacts are mostly due to $\mathrm{NO}_{x}$ and particulate matter emissions in the production process of SNG and FT diesel as the production plants are modeled as scale-ups of pilot plants. These emissions will certainly be reduced by installing emission control systems in real plants (which will, on the other hand, slightly reduce the efficiency and increase the costs and GHG emissions). Detailed studies on emissions from larger SNG and FT diesel plants (around $500 \mathrm{MW}_{\text {th,in }}$ ) would be interesting.

For other impacts like human toxicity ${ }^{\mathrm{d}}$, the electricity mix and the electric vehicle production cause significantly higher emissions due to lignite burning and battery production. However, there are high uncertainties in the toxicity of the battery production phase.

The aggregated ReCiPe Total score shows that biogenic electricity seems to be a promising compromise for commuter cars (keeping in mind the environmental impacts for the battery production). For all-purpose cars, SNG has less impact in most categories than FT diesel with nearly the same GHG reduction potential and therefore performs best for the ReCiPe Total score.

\section{GHG mitigation costs}

As stated in Subsection 'Cost-effectiveness analysis: GHG mitigation costs', an easy but accurate way to present mitigation costs is a cost difference over emission mitigation plot. This is depicted in Figure 5 for GHG emissions. All numeric results are also summed up in the Additional file 1: Table S1.

For the commuter car, all three biogenic fuels show similar results with respect to costs and GHG emissions. It essentially depends on the scenario assumptions which fuel-car combination has the lowest GHG mitigation costs, with a slight preference for FT diesel. Electric cars combined with biogenic electricity show a high cost uncertainty due to electric car prices and will only have comparable GHG mitigation costs in comparison to the other fuels if electric cars will obtain a high market penetration in the next years, as assumed in the scenario e-mobility age (E).

Applying Equation 4 (page 6) with a valuation of GHG emissions of $m=100 € / \mathrm{t} \mathrm{CO}_{2}$-Eq, FT diesel performs best in the business as usual (B) scenario, followed by biogenic electricity in e-mobility age (E) and SNG in the gas age (G) scenarios. Technically, natural gas performs best in scenario G, but the possible GHG reduction is low and it is not a renewable fuel.

For the ReCiPe Total score and $m=1 € /$ point, FT diesel in scenario $B$ is the best alternative, followed by biogenic electricity in scenario $\mathrm{E}$ and SNG in scenario G.

This means that the most cost-efficient biogenic fuel for GHG mitigation and ReCiPe Total mitigation depends on the market penetration of electric and gaseous fuel cars and on the subsequent learning curves and technical optimizations of those cars.

For the all-purpose car, regardless of the scenario, natural gas has the lowest GHG reduction costs (because of cost savings compared to diesel), even though the possible GHG reductions are quite small. The next best solution is SNG in gas age with mitigation costs of $107 € / \mathrm{tCO}_{2}$-Eq. The electric all-purpose car is too expensive to be considered a cost-effective solution for GHG mitigation.

When applying Equation 4 (page 6) with $m=100 € / \mathrm{t}$ $\mathrm{CO}_{2}$-Eq for GHG emissions, natural gas performs best followed by SNG (and FT diesel in scenario B), with biogenic electricity far behind.

Natural gas also performs best when applying Equation 4 to the ReCiPe Total impact score with $m=1 € /$ point. SNG is the second best alternative with a much bigger mitigation potential but at slightly higher mitigation costs.

So for all-purpose cars, cost-effective GHG or ReCiPe Total mitigation can best be achieved via gaseous fuels. Natural gas not only saves GHG emissions but is also cheaper than diesel while SNG offers higher GHG mitigation at around $100 € / \mathrm{t} \mathrm{CO}_{2}$-Eq.

\section{Comparison with other studies}

Regarding SNG and FT diesel from forest residues for Germany in the year 2020, the obtained parameters for the comparison of electricity such as total costs of ownership, consumption, and electricity mix composition correspond well with numerous similar studies $[47,74,75]$ despite minor differences in the assumptions. However, most of those studies do not include different car types and driving behavior [76] although these greatly influence the results. We suggest using at least two different mobility patterns and car types: the smaller commuter car and the bigger all-purpose car to better reflect specific advantages of each fuel for different car usage patterns. Furthermore, we considered realistic driving cycles for emission and consumption measurements and a weighting of the 


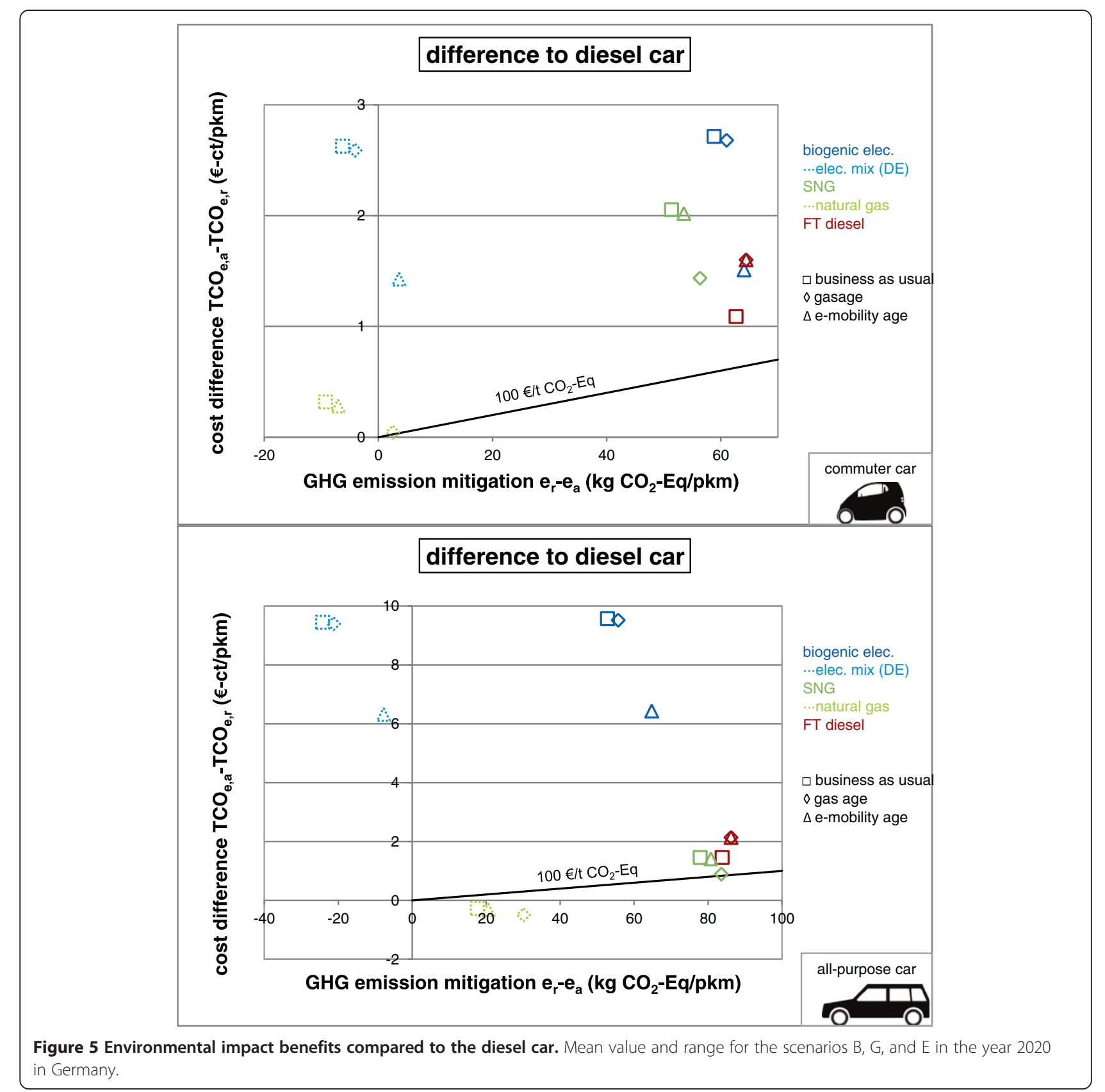

different parts of the driving cycle depending on the mobility pattern.

\section{Uncertainties}

Uncertainties in this study arise from the fuel conversion because most conversion plants were not available in the required size. Eutrophication potentials for SNG and FT diesel were high because SNG and FT plants were modeled as a scale-up of pilot plants. Eutrophication could probably be lowered by installing state-of-the-art emission control. Detailed LCA studies of commercial SNG and FT plants are needed to lower uncertainties.
Another uncertain parameter is the battery price (c.f. subsection 'Economic analysis' in Additional file 1), and the production process resulting in a quite high bandwidth of costs for the electric car. We considered uncertainties by showing the results for a range of input parameters in the three scenarios and by performing sensitivity analyses; nevertheless, the results would benefit from studies on the mentioned uncertain parameters.

\section{Conclusions}

When comparing the three fuels from forest residues, we showed that electric cars fuelled with biogenic electricity 
have a potential as commuter cars - both for cost-efficient GHG reduction and for most of the other environmental impacts. Precondition for this is a fast market penetration of electric cars in the next years so that economies of scales (as considered in this study) take effect. For bigger all-purpose cars, SNG seems very promising with the additional benefits of being on the verge of commercial availability, and it may be commercially attractive in relatively small plants, in contrast to FT diesel. If GHG reductions are valued at less than $100 € / \mathrm{t} \mathrm{CO}_{2}$-Eq, natural gas represents a very cheap way to reduce GHG emissions in bigger cars. The development of an infrastructure for natural gas would also help the market penetration of SNG. Constraints to the spread of gaseous fuel cars are customer acceptance and fears of explosion.

It should be noted that fuels from biogenic residues will not be able to replace fossil fuels in Germany in total but can be a viable asset. Potential analyses for Baden-Württemberg [2] showed that if all forest residues were used to produce biogenic electricity for commuter cars, roughly $25 \%$ of the fuels needed for commuter cars could be replaced. This would be significantly less for SNG (7\% to $10 \%)$ or FT diesel (6\% to $8 \%)$ and even less when including the all-purpose cars. However, in other regions of the world, the potential is higher [77]. When extending this study to those regions, car choices, driving patterns and the electricity mix should be adapted to local conditions.

We chose to model only the use of forest residues as energy source for the biogenic fuels. The results can be transferred to most biogenic residues (like straw) with minor modifications. This choice was made to avoid land use conflicts and land use change. In real life and without political regulations, other types of resources like energy crops would certainly also be used to produce those fuels. This would influence the results significantly, especially if taking into account the GHG emissions caused by land use change [78-80].

To conclude, it is important to clearly define the main goals of using biogenic fuels: maximum GHG abatement, GHG abatement at low cost, maximum fossil fuel replacement, overall environmental performance or maintenance of high car ranges via gaseous or liquid fuels. As shown in this study, the performance of a biogenic fuel strongly depends on this goal definition, and goals can be conflicting.

Last but not least, we would like to emphasize that parameters like occupancy, car sharing, driving style, and choice of transportation could reduce environmental impacts of individual mobility far more and in a cheaper way than biogenic fuels. For example, half the car trips in Germany are shorter than $6 \mathrm{~km}$ and could be replaced at least partially by public transport, bicycles, and walking.

\section{Endnotes}

${ }^{\mathrm{a}}$ Costs and technical progress depend on worldwide car production, not only on German.

${ }^{\mathrm{b}}$ The compact cars are divided based on driving characteristics. The remaining 20\% include sports cars, sport utility vehicles (SUVs), and bigger vehicles like mobile homes (Additional file 1: Figure S1 for more details).

${ }^{\mathrm{c}}$ As well as photochemical oxidation and particulate matter.

${ }^{\mathrm{d}}$ And also ecotoxicity and ozone depletion.

\section{Additional file}

\begin{abstract}
Additional file 1: Mobility patterns, economic analysis, and additional results [81-83]. Figure S1. Vehicle registrations in Germany per month by car class. Figure S2. Distribution of yearly driven distance by car class in Germany. Figure S3. Distribution of trip length by car category in Germany. Figure S4. Relation between trip length and occupancy in Germany. Figure S5. Speed profile of CADC and NEDC. Figure S6. ReCiPe Total impact: range for scenarios B, G, and E in 2020. Table S1. GHG emissions and cost differences to diesel car for all fuel-car combinations in the year 2020
\end{abstract}

\section{Abbreviations}

B: business as usual, scenario name, reference scenario; CADC: common ARTEMIS driving cycle, speed profile representing realistic European driving conditions; CNG: compressed natural gas, gas containing mainly methane; $\mathrm{CO}_{2}$ : carbon dioxide; $\mathrm{CO}_{2}$-Eq: $\mathrm{CO}_{2}$ equivalent, unit for measurement of greenhouse gas emissions; $\mathrm{Ct}$ : $€$-ct, Euro-cent, if not stated otherwise, all monetary values are inflation adjusted for the year 2011; E: E-mobility age, scenario name, high production number of electric cars; FT: Fischer tropsch, process to synthesize hydrocarbons from synthetic gas; G: gas age, scenario name, high production number of gaseous fuel cars; GHG: greenhouse gas, designation for gases causing global warming; LCA: life cycle analysis, method modeling all material flows over the life cycle of a product; $\mathrm{m}^{2}$ : square meters; NEDC: New European driving cycle, speed profile that is used to measure tailpipe emissions of cars, mandatory for European cars; $\mathrm{NO}_{x}$ : nitrogen oxides, includes $\mathrm{NO}$ and $\mathrm{NO}_{2}$; occupancy: mean number of passengers per car; pkm: passenger kilometer, unit for measuring the function of a passenger car. Represents the transportation of one passenger over $1 \mathrm{~km}$ (if a car carries two passengers, then $1 \mathrm{pkm}$ is reached after 0.5 $\mathrm{km})$; ReCiPe: life cycle impact assessment method created by the National Institute of Public Health and the Environment (RIVM), the Centre of Environmental Science of Leiden University $(\mathrm{CML})$, and by PRé Consultants; SNG: substitute natural gas, a gas with equivalent properties to natural gas (elsewhere also used for synthetic natural gas); SUV: sport utility vehicle; t: ton, 1,000 kg; TCO: total costs of ownership, sum of all costs arising from the ownership of a car (car acquisition, fuel costs, insurance, maintenance, etc.).

\section{Competing interests}

The authors declare that they have no competing interests.

\section{Authors' contributions}

$\mathrm{OH}$ modeled the fuel use and biogenic fuel production and drafted the manuscript. LL, SK, and GK modeled the biogenic fuel production and supported drafting the manuscript and conceiving of the study. US helped with the acquisition and analysis of the car life cycle data. All authors read and approved the final manuscript.

\section{Author details}

${ }^{1}$ Institute for Technology Assessment and Systems Analysis (ITAS), Karlsruhe 76021, Germany. ${ }^{2}$ Institute for Reciprocating Engines (IFKM), Karlsruhe Institute of Technology, Karlsruhe 76131, Germany.

Received: 14 September 2013 Accepted: 8 April 2014 Published: 20 May 2014 


\section{References}

1. Tarancón Morán MÁ, del Río GP (2007) Structural factors affecting landtransport CO2 emissions: a European comparison. Transp Res Part D: Transp Environ 12:239-253, doi:10.1016/j.trd.2007.02.003

2. Kappler G (2008) Systemanalytische Untersuchung zum Aufkommen und zur Bereitstellung von energetisch nutzbarem Reststroh und Waldrestholz in Baden-Württemberg: eine auf das Karlsruher bioliq-Konzept ausgerichtete Standortanalyse. Uni Freiburg, Freiburg

3. International council on clean Transportation (2013) European Vehicle Market Statistics - Pocketbook 2013. International council on clean Transportation, Berlin

4. Pelkmans L, Debal P (2006) Comparison of on-road emissions with emissions measured on chassis dynamometer test cycles. Transp Res Part D: Transp Environ 11:233-241, doi:10.1016/j.trd.2006.04.001

5. Hausberger S (2010) Fuel Consumption and Emissions of Modern Passenger Cars. In: TU Graz, Bundesministerium für Land- und Forstwirtschaft, Umwelt und Wasserwirtschaft, Graz

6. Hurtig O (2013) Techno-ökonomischer Vergleich des Einsatzes von Strom, SNG und Fischer-Tropsch-Kraftstoff aus Biomasse im Pkw-Bereich. Karlsruher Institut für Technologie, Karlsruhe

7. Wilms FEP (2006) Szenariotechnik: vom Umgang mit der Zukunft. Haupt, Bern

8. IANGV (2012) 2011 Natural Gas Vehicle Statistics Published. http://www. iangv.org/2012/05/2011-natural-gas-vehicle-statistics-released/. Accessed 17 Jun 2013

9. lea EVI (2013) Global EV outlook. Electric vehicles initiative of the clean energy. Ministerial, Paris

10. OICA (2012) 2011 statistics. http://oica.net/category/production-statistics/ 2011-statistics/. Accessed 17 Jun 2013

11. Leible L, Kälber S, Kappler G, Lange S, Nieke E, Proplesch P, Wintzer D, Fürniß B (2007) Kraftstoff, Strom und Wärme aus Stroh und Waldrestholz: eine systemanalytische Untersuchung. Forschungszentrum Karlsruhe, Karlsruhe

12. Prognos AG, EWI GWS (2010) Energieszenarien für ein Energiekonzept der Bundesregierung. Prognos AG, Basel/Köln/Osnabrück

13. PIK, IIRM (2011) Der Einstieg in den Ausstieg: Energiepolitische Szenarien für einen Atomausstieg in Deutschland. PIK, Potsdam

14. EWI, EEFA (2008) Energiewirtschaftliches Gesamtkonzept 2030 Bundesverband der Energie- und Wasserwirtschaft, Berlin, Potsdam und Frankfurt am Main

15. McKinsey (2010) A portfolio of power-trains for Europe: a fact-based analysis.

16. Leible L, Källber S, Kappler G, Eltrop L, Stenull M, Lansche J, Poboss N, Stürmer B, Kelm T, Köppel W (2012) Perspektiven für Bio-Erdgas Teil I: Bereitstellung aus nasser und trockener Biomasse. BWK 64:21-27

17. Perlwitz H (2007) Der Erdgasmarkt für den Kraftwerkssektor unter CO2Minderungsverpflichtungen: eine modellgestützte Analyse des europäischen Energiemarktes. Universität Karlsruhe, Karlsruhe

18. Matthes FC (2010) Energiepreise für aktuelle Modellierungsarbeiten. Regressionsanalytisch basierte Projektionen, Teil 1: Preise für Importenergien und Kraftwerksbrennstoffe. Öko-Institut, Berlin

19. EIA (2011) Annual Energy Outlook 2011. ElA, Washington

20. Schade B, Wiesenthal T (2011) Biofuels: a model based assessment under uncertainty applying the Monte Carlo method. J Policy Model 33:92-126, doi:10.1016/j.jpolmod.2010.10.008

21. Sunde K, Brekke A, Solberg B (2011) Environmental impacts and costs of hydrotreated vegetable oils, transesterified lipids and woody BTL-a review. Energies 4:845-877, doi:10.3390/en4060845

22. IEA (2011) World Energy Outlook 2011. OECD/IEA, Paris

23. IEA (2010) World Energy Outlook 2010. OECD/IEA, Paris

24. Wietschel M, Bünger U, Weindorf W (2010) Vergleich von Strom und Wasserstoff als CO2-freie Endenergieträger. Fraunhofer ISI, LBST, Karlsruhe

25. Hischier R, Weidema B, Althaus HJ, Bauer C, Doka G, Dones R, Frischknecht R, Hellweg S, Humbert S, Jungbluth N (2010) Implementation of Life Cycle Impact Assessment Methods, Ecoinvent report No. 3, v2. 2. Swiss Centre for Life Cycle Inventories, Dübendorf, $\mathrm{CH}$

26. BEE AEE (2009) Der Strommix im Jahr 2020: Erneuerbare Energien sichern 47\% der Versorgung. Agentur für Erneuerbare Energien, Bundesverband Erneuerbare Energien

27. BMWi, BMU (2010) Energiekonzept für eine umweltschonende, zuverlässige und bezahlbare Energieversorgung. BMWi, BMU, Berlin
28. Bandivadekar A, Bodek K, Cheah L, Evans C, Groode T, Heywood J, Kasseris E, Kromer M, Weiss M (2008) On the road in 2035: reducing transportation's petroleum consumption and GHG emissions. MIT laboratory for energy and the environment, Cambridge

29. IEA (2011) Technology Roadmap: Electric and plug-in hybrid electric vehicles. $\mathrm{OECD/IEA}$, Paris

30. Kalhammer FR, Kopf BM, Swan D, Roan VP, Walsh MP (2007) Status and Prospects for Zero Emissions Vehicle Technology. State of California Air Resources Board. Sacramento, California

31. Kromer M, Heywood J (2007) Electric Powertrains: Opportunities and Challenges in the U.S. Light-Duty Vehicle Fleet. Sloan Automotive Laboratory, MIT, Cambridge

32. Mayer T, Kreyenberg D, Wind J, Braun F (2012) Feasibility study of 2020 target costs for PEM fuel cells and lithium-ion batteries: a two-factor experience curve approach. Int J Hydrog Energy 37:14463-14474, doi:10.1016/j.jijhydene.2012.07.022

33. Öko-Institut, DLR (2009) RENEWBILITY Stoffstromanalyse nachhaltige Mobilität im Kontext erneuerbarer Energien bis 2030. Bundesministerium für Umwelt, Naturschutz und Reaktorsicherheit, Berlin

34. Competence E (2011) Projekt Competence E. http://www.competence-e.kit edu/index.php. Accessed 3 Feb 2012

35. Schmid S (2012) Marktperspektiven zukünftiger Fahrzeugkonzepte - Wettbewerb technischer Lösungen, der Kunde und die Rahmenbedingungen.

36. Eckstein L, Schmitt F, Hartmann B (2010) Leichtbau bei Elektrofahrzeugen. ATZ Automobiltechnische Zeitschrift 112:788-795, doi:10.1007/BF03222207

37. Goede M, Stehlin M, Rafflenbeul L, Kopp G, Beeh E (2008) Super light car — lightweight construction thanks to a multi-material design and function integration. Eur Transp Res Rev 1:5-10, doi:10.1007/s12544-008-0001-2

38. Held M (2011) LCA E-Mobility: Current results of the Fraunhofer System Research for Electromobility (FSEM) and need for further research.

39. Kloess M, Weichbold A, Könighofer K (2009) Technical, Ecological and Economic Assessment of Electrified Powertrain Systems for Passenger Cars in a Dynamic Context (2010 to 2050).

40. TNO, IEEP, LAT (2006) Review and analysis of the reduction potential and costs of technological and other measures to reduce CO2-emissions from passenger cars. TNO, Delft

41. Weiss M, Heywood J, Drake E, Schafer A, Auyeung F (2000) On The Road In 2020 - A life-cycle analysis of new automobile technologies. MIT Laboratory for Energy and the. Environment, Cambridge

42. Holmberg K, Andersson P, Erdemir A (2012) Global energy consumption due to friction in passenger cars. Tribol Int 47:221-234, doi:10.1016/j. triboint.2011.11.022

43. Kushnir D, Sandén BA (2011) Multi-level energy analysis of emerging technologies: a case study in new materials for lithium ion batteries. J Clean Prod 19:1405-1416, doi:10.1016/j.jclepro.2011.05.006

44. Linssen J, Bickert S, Hennings W, Schulz A, Marker S, Waldowski P, Schindler V, Mischinger S, Schmidt A, Abbasi E, Strunz K, Maas H, Schmitz P, Günther C, Schott B, Danzer M, Weinmann O, Lindwedel E (2012) Netzintegration von Fahrzeugen mit elektrifizierten Antriebssystemen in bestehende und zukünftige Energieversorgungsstrukturen. Forschungszentrum Jülich, Jülich

45. Parker (2010) Electric and Hybrid Electric Drivetrain Solutions.

46. Spicher U (2012) Analyse der Effizienz zukünftiger Antriebssysteme für die individuelle Mobilität. MTZ Motortechnische Zeitschrift 02(2012):98-105

47. JEC, Joint Research Centre, EUCAR, CONCAWE (2011) Well-to-Wheels study Version 3C.

48. Berggren C, Magnusson T (2012) Reducing automotive emissions-the potentials of combustion engine technologies and the power of policy. Energy Policy 41:636-643, doi:10.1016/j.enpol.2011.11.025

49. Mahr B, Taylor J, Bassett M (2012) Kraftstoffverbrauchsvorteile im realen Fahrbetrieb durch Abgasrückführung bei modernen DownsizingMotoren.

50. Pischinger S (2011) Antriebsentwicklung der Zukunft. ATZ 2011-03:136-14

51. Schmuck-Soldan S, Cloos LK, Cleary DJ, Santoso H (2012) Aufladekonzepte für den Ottomotor der Zukunft.

52. Tilagone R, Venturi S, Monnier G (2006) Natural gas - an environmentally friendly fuel for urban vehicles: the smart demonstrator approach. Oil and Gas Science and Technology 61:155-164

53. Wallentowitz H, Freialdenhoven A, Olschewski I (2008) Strategien in der Automobilindustrie: Technologietrends und Marktentwicklungen. Vieweg + Teubner, Wiesbaden 
54. Wang MQ (1997) Mobile source emission control cost-effectiveness: issues, uncertainties, and results. Transp Res Part D: Transp Environ 2:43-56, doi:10.1016/S1361-9209(96)00017-X

55. Wright TP (1936) Factors affecting the cost of airplanes. JANS 3:122-128

56. Remer DS, Nieto AP (1995) A compendium and comparison of 25 project evaluation techniques. Part 1: net present value and rate of return methods. Int J Prod Econ 42:79-96, doi:10.1016/0925-5273(95)00104-2

57. KBA (2011) Alter der Fahrzeuge.

58. IPCC (2007) Fourth Assessment Report: Climate Change 2007 (AR4), Intergovernmental Panel on Climate Change (IPCC). Cambridge University Press, New York

59. Goedkoop M, Heijungs R, Huijbregts M, De Schryver A, Struijs J, Van Zelm R (2009) ReCiPe 2008: a life cycle impact assessment method which comprises harmonised category indicators at the midpoint and the endpoint level, Report I: Characterisation. Ministerie van VROM, Den Haag

60. Hauschild M, Potting J (2004) Spatial differentiation in life cycle impact assessment-the EDIP-2003 methodology. Guidelines from the Danish EPA. Danish Environmental Protection Agency, Copenhagen

61. Querini F, Morel S, Boch V, Rousseaux P (2011) USEtox relevance as an impact indicator for automotive fuels. Application on diesel fuel, gasoline and hard coal electricity. The International Journal of Life Cycle Assessment 16:829-840, doi:10.1007/s11367-011-0319-1

62. Rosenbaum RK, Bachmann TM, Gold LS, Huijbregts MAJ, Jolliet O, Juraske R, Koehler A, Larsen HF, MacLeod M, Margni M, McKone T, Payet J, Schuhmacher M, Meent D, Hauschild M (2008) USEtox-the UNEP-SETAC toxicity model: recommended characterisation factors for human toxicity and freshwater ecotoxicity in life cycle impact assessment. The International Journal of Life Cycle Assessment 13:532-546, doi:10.1007/s11367-008-0038-4

63. Guinée JB, Gorrée M, Heijungs R, Huppes $G$, Kleijn R, de Koning A, van Oers L, Wegener Sleeswijk A, Suh S, Udo de Haes HA, de Bruijn H, van Duin R, Huijbregts MAJ (2002) Handbook on life cycle assessment. Operational guide to the ISO standards. Kluwer Academic Publishers, New York, Boston, Dordrecht, London, Moscow

64. Kannan R, Leong KC, Osman R, Ho HK (2007) Life cycle energy, emissions and cost inventory of power generation technologies in Singapore. Renew Sust Energ Rev 11:702-715, doi:10.1016/j.rser.2005.05.004

65. Halsnæs K, Mackenzie GA, Swisher JN, Villavicencio A (1994) Comparable assessment of national GHG abatement costs. Energy Policy 22:925-934, doi:10.1016/0301-4215(94)90040-X

66. McKinsey (2010) Impact of the financial crisis on carbon economics Version 2.1 of the Global Greenhouse Gas Abatement Cost Curve. McKinsey, New York

67. dena (2011) Erdgas und Biomethan im künftigen Kraftstoffmix. Deutsche Energie-Agentur GmbH (dena), Berlin

68. Dry ME (2002) High quality diesel via the Fischer-Tropsch process - a review. J Chem Technol Biotechnol 77:43-50, doi:10.1002/jctb.527

69. KBA (2012) Monatliche Neuzulassungen 2009-2012. http://www.kba.de/DE/ Statistik/Fahrzeuge/Neuzulassungen/MonatlicheNeuzulassungen/ monatl_neuzulassungen_node.html. Accessed 6 June 2014

70. infas, DLR (2010) Mobilität in Deutschland 2008. Datensätze, Bonn und Berlin

71. André M (2004) The ARTEMIS European driving cycles for measuring car pollutant emissions. Sci Total Environ 334-335:73-84, doi:10.1016/j. scitotenv.2004.04.070

72. infras (2010) Handbuch Emissionsfaktoren des Straßenverkehrs (HBEFA), Version 3.1. Umweltbundesamt, Berlin

73. Bach C, Lienin S (2007) Emissionsvergleich verschiedener Antriebsarten in aktuellen Personenwagen. EMPA, Dübendorf

74. Faria R, Moura P, Delgado J, de Almeida AT (2012) A sustainability assessment of electric vehicles as a personal mobility system. Energy Convers Manag 61:19-30, doi:10.1016/j.enconman.2012.02.023

75. Sharma R, Manzie C, Bessede M, Brear MJ, Crawford RH (2012) Conventional, hybrid and electric vehicles for Australian driving conditions - part 1: technical and financial analysis. Transportation Research Part C: Emerging Technologies 25:238-249, doi:10.1016/j.trc.2012.06.003

76. Hawkins T, Gausen O, Strømman A (2012) Environmental impacts of hybrid and electric vehicles - a review. The International Journal of Life Cycle Assessment 17:997-1014, doi:10.1007/s11367-012-0440-9

77. Bright RM, Strømman AH (2009) Life cycle assessment of second generation bioethanols produced from Scandinavian boreal forest resources. J Ind Ecol 13:514-531, doi:10.1111/j.1530-9290.2009.00149.x
78. Hill J, Nelson E, Tilman D, Polasky S, Tiffany D (2006) Environmental, economic, and energetic costs and benefits of biodiesel and ethanol biofuels. PNAS 103:11206-11210, doi:10.1073/pnas.0604600103

79. Lechon Y, Cabal H, Sáez R (2011) Life cycle greenhouse gas emissions impacts of the adoption of the EU Directive on biofuels in Spain. Effect of the import of raw materials and land use changes. Biomass Bioenergy 35:2374-2384, doi:10.1016/j.biombioe.2011.01.036

80. Fargione J, Hill J, Tilman D, Polasky S, Hawthorne P (2008) Land clearing and the biofuel carbon debt. Science 319:1235-1238, doi:10.1126/science.1152747

81. RL 70/220/EWG (1970) Richtlinie 70/220/EWG des Rates vom 20. März 1970 zur Angleichung der Rechtsvorschriften der Mitgliedstaaten über Maßnahmen gegen die Verunreinigung der Luft durch Abgase von Kraftfahrzeugmotoren mit Fremdzündung.

82. Deutsche Bundesbank (2013) Abzinsungszinssätze gemäß § 253 Abs. 2 HGB

83. De Neufville R (2007) Choice of discount rate, Part of the MIT course 'Engineering Systems Analysis for Design'.

doi:10.1186/2192-0567-4-12

Cite this article as: Hurtig et al:: Alternative fuels from forest residues for passenger cars - an assessment under German framework conditions. Energy, Sustainability and Society 2014 4:12.

\section{Submit your manuscript to a SpringerOpen ${ }^{\odot}$ journal and benefit from:}

- Convenient online submission

- Rigorous peer review

- Immediate publication on acceptance

- Open access: articles freely available online

- High visibility within the field

- Retaining the copyright to your article

Submit your next manuscript at $>$ springeropen.com 